\title{
The management of the faeces passed by under five children: an exploratory, cross- sectional research in an urban community in Southwest Nigeria
}

Olufemi Oludare Aluko*, Olusegun Temitope Afolabi, Emmanuel Abiodun Olaoye, Adeyinka Daniel Adebayo, Seun Oladele Oyetola and Oluwaseun Olamide Abegunde

\begin{abstract}
Background: Safe management of faeces (SMoF) and environmental contamination by faecal pathogens have been extensively researched although the SMoF in under-five children has been perennially neglected perhaps due to the misconception that it is harmless. This research, therefore, studied the situation, to determine the magnitude and dimensions of the problem aimed at making policy level stakeholders aware of child faeces management systems and so, inform evidence-based implementation of child and health-related programmes in Nigeria.

Methods: The study utilized an exploratory cross-sectional design and a multi-stage sampling technique to identify 300 respondents from 12 randomly selected streets from 4 wards in Ife central local government area. The study collected data with a pretested questionnaire which included direct observations of child defecation practices and existing toilet facilities. Cleaned data were analyzed by IBM-SPSS version 20 with child faeces management outcomes as the dependent variable.

Results: The mean age of respondents' and monthly income (mode) were $30.8 \pm 7.5$ years and $10,000.00$ ( $\$ 28.60)$. Most respondents were mothers to the under five children (84.7\%), had a secondary education (72.0\%) and were semi-skilled (57.0\%). The caregivers had access to improved water sources (93.7\%), improved toilets (64.3\%), with 64\% and 53.7\% having above average scores in knowledge and attitudes, respectively. In the study, 19.7\% and 69. $0 \%$ of caregivers practiced safe disposal of faeces passed by the under five child during the day and at night respectively, though most caregivers (94.3\%) omitted steps in the safe management of child faeces chain. The under five diarrhoea prevalence rate was $13.7 \%$ and unsanitary passage of child faeces is associated with four folds likelihood of having diarrhoea $(p=0.001)$. The caregivers whose under five children practiced safe sanitation were rich $(p=0.009)$ and knowledge was significantly associated with ownership of household toilet $(P=0.037)$, night faeces management chain practice $(P<0.001)$ and disposal of anal cleaning materials $(P=0.002)$. Handwashing was significantly associated with household toilet $(P<0.001)$, wealth $(P<0.001)$, under five child defecation preferences during the day $(P<0.001)$ and at night $(P=0.008)$.

(Continued on next page)
\end{abstract}

\footnotetext{
* Correspondence: ooaluko@gmail.com

Department of Community Health, Obafemi Awolowo University, lle-Ife, Nigeria
} 
(Continued from previous page)

Conclusion: The high knowledge and positive attitudes exhibited by the caregivers were at variance with practice. Where under five children defecate during the day were influenced by the disposal of their anal cleaning materials, distance to the toilet and caregivers' education. The findings highlight the dangers of unsanitary disposal of child faeces and the need to strengthen the related policies that can increase caregivers awareness and practice at all levels and in all livelihood domains.

Keywords: Child faeces disposal;safe management of faeces, Faeces management chain, Childhood illnesses, Sanitation and hygiene, Nigeria

\section{Background}

Environmental sanitation in practice applies the physical and biological principles to improve and control factors in the environment. Sanitation is an important foundation required towards the protection of public health and human welfare, which has assumed prominence in the international development agenda as a basic human right [1-3].

In 2013, the Nigeria Demographic and Health Survey (NDHS) revealed that households in Gombe state (Northeast Nigeria) has the highest access to improved sanitation facilities (66.5\%) while those in Zamfara state (Northwest Nigeria) has the lowest access (6.9\%) to improved sanitation facilities [4]. In addition, $30.1 \%$ households had improved, non-shared toilet facilities being used by $34.0 \%$ of the population with coverage skewed towards urban residence [4]. In Osun State, where this study occurred, only $16.1 \%$ of households had access to improved sanitation facilities, mostly in urban residential areas being used by $19.2 \%$ of the population [4]. As at 2015 , the proportions of people that used improved (29\%), shared (24\%), other unimproved (22\%) toilet facilities were below those required to meet the sanitation target of the Millenium Development Goal (MDG) seven, that sought to halve the proportion of people without sustainable access to basic sanitation in Nigeria [5]. The sanitation indices in Nigeria contributed to the poor human development index, typified by the high infant mortality rate (72.7 per 1000 live births) and under five mortality rate (157 per 1000 live births) [6]. The above statistics predisposes young children, who tend to defecate in areas where other susceptible children are exposed while learning to walk or playing in their premises, with frequent hands to mouth contacts, thus increasing the prevalence of faeces related diseases in such places and the risk of environmental enteropathy [7-9].

In 2012, the World Health Organisation/UNICEF Joint Monitoring Programme (JMP) reported that about 121.9 million Nigerians lacked access to improved excreta disposal facilities while 38.8 million Nigerians practice open defecation. This meant that only $28 \%$ of Nigerian households had access to improved sanitation conveniences. The analysis of the Nigeria's National Demographic
Health Survey (NDHS), 2013 data, authored by Water and Sanitation Program of the World Bank reported that only $23 \%$ of households dispose of their youngest child's faeces in an improved sanitation facility [10]. The prevalence of risky disposal of children's faeces in Nigeria is higher among households without access to improved toilet, probably among dwellers in rural areas and urban slums. These are where poorer households, and those that practice open defecation predominate [10]. Safe excreta disposal in children is equally as important as in adults [11, 12], though efforts have been concentrated on promoting the construction, ownership and use of adult toilet facilities globally. The safest way to dispose of faeces of an under five child is to help him/her use the toilet or latrine. However, for the very young child, the faeces could be rinsed into the toilet or buried, which is synonymous to cat sanitation in the first instance instead of open defecation [11-13]. Unsafe faeces disposal practices include those left in the open, thrown into the garbage, put/washed/rinsed into open drains, eaten by animals where faecal pathogens predominate and spread, from multiple environmental media to human populations [14].

The World Health Organisation (WHO) attributed $88 \%$ of diarrhoea associated mortality in the world, to unsafe water, poor sanitation, or hygiene. Over $99 \%$ of diarrhoea, associated mortality occurred in developing countries while about 8 in 10 deaths occur in children [15]. In Nigeria, the diarrhoea prevalence rate (18.8\%) is one of the highest in Africa and above the Sub-Saharan Africa average of $16 \%$. Diarrhoea accounted for over $16 \%$ of child deaths in Nigeria and an estimated 150,000 deaths mainly among children under five annually. This is caused predominantly by poor sanitation and poor hygiene practices, especially when the faeces of $47 \%$ of children Under five years old in Nigeria is disposed of through unsanitary methods [10]. In the context of this research, the caregiver was any adult person, who could be a family member or paid helper that cares for a child between 1 and 59 months old, for at least two consecutive months. Hence, caregivers could be grandparents, parents, aunts, formal and informal institutions such as a creche, where they are catered for. From available statistics, the practice of safe child faeces management 
remains low in Nigeria and factors associated with the practice of caregivers have only been documented in a few literature $[10,16]$. The study, therefore, explored the magnitudes, dimensions and determinants of child faeces management in an urban city in Nigeria.

\section{Methods}

\section{Description of the study location}

The study was conducted in Osun State in South-western Nigeria. Osun State has a tropical climate with distinct wet and dry seasons. The study took place in Ile-Ife, the headquarter of Ife Central and Ife East Local Government Areas (LGAs). Ile-Ife is bounded by Ife North, Ife East, Ife South and Atakunmosa West LGAs.

\section{Study design}

The study utilized an exploratory cross-sectional design.

\section{Sample size determination}

The minimum sample was calculated by using the formula for estimating single proportions [17];

$$
\mathrm{n}=\mathrm{Z}^{2} \mathrm{P}(1-\mathrm{P}) / \mathrm{d}^{2}
$$

$\mathrm{n}=$ minimum sample size

$\mathrm{Z}=$ standard normal variate, at 1.96 , which corresponds to the $95 \%$ confidence level.

$\mathrm{P}=23 \%$, the proportion of under five caregivers that practice improved excreta disposal in Nigeria [10].

$\mathrm{d}=$ degree of accuracy desired or maximum allowable margin of error, it was set at 5\% (0.05).

This gave a sample size 273, which was increased to 300 with $10 \%$ added for attrition, inappropriately filled or missing questionnaires.

\section{Sampling technique}

The study utilized a multi-staged sampling technique. Ife Central LGA has eleven wards from which four were selected by simple random sampling. This was followed by the selection of three streets from the respective sample frame by simple random sampling. Houses in the selected streets were identified by systematic sampling method. Trained enumerators were assigned clusters of households delimited by road networks and footpaths. In selected houses, if there were more than one eligible households, simple random sampling was used to identify the index household that participated in the study. Only one household is eligible to be included in the study per house.

Each enumerator started at the proximate house, closest to the main road, soliciting every third household in a clockwise manner until the minimum sample for the street has been covered, according to the works of Russel et al. [18]. Three hundred and fifty-nine households were approached out of which 7.5\% $(n=27)$ were not eligible by the inclusion criteria while $8.9 \%$ $(n=32)$ declined to participate, though eligible. A total of 25 households were recruited per street.

\section{Inclusion criteria}

For caregivers to be enrolled in the study, they should have satisfied the conceptual definition of caregivers provided for the study; be willing to participate and be resident or working within the randomly selected households in the study area.

\section{Data collection and analysis}

The study took place between February and April 2016. The study utilized a pre-tested questionnaire (refer to Additional file 1), which contained sections on sociodemographic information, knowledge, attitudes and practices on child faeces passage, transport, disposal and hygiene of children and caregivers. A direct observation was used to document practices on the child faeces management chain (faeces passage, transportation, transport tools, disposal, hygiene of the transport tools and handwashing), where the under five children defecated during the period of data collection and observation. During the data collection period, if the index child in any of the enrolled households either defecate or defecating when the enumerators were there, then the process is recorded and reported in the study. The observations were not triggered but only happened and recorded during the data collection phase of the study. The study also observed and recorded the features of the household toilet facilities and presence of human excreta around the premises.

The diseases presented in this study were self-reported by the caregivers of under-five children, based on a 2week recall period. However, the enumerators were trained to recognize the signs/symptoms and probed for each of the four diseases prior to making informed decisions. The completed questionnaires were checked and cleaned for completeness, accuracy and coded. The data were entered using EpiData 3.1 (EpiData Association, Odense, Denmark) and analyzed by using IBM-SPSS version 20. Socio-demographic characteristics and other univariate variables were presented by summary statistics using mean \pm standard deviation and mode for continuous variables and frequency/percentages for categorical variables.

In this study, a household was defined as all persons who shared a cooking pot [19]. The questionnaire had 10 and 11 question items on knowledge and attitude variables. Prior to analysis, correct responses were coded as ' 1 ' while incorrect responses were coded ' 0 ' for knowledge questions. The respondents' attitude was measured by 5 point Likert scale: "Strongly agree", "agree", 
"undecided", "disagree" and "strongly disagree" and scored 5, 4, 3, 2 and 1, respectively. For knowledge and attitude variables, the aggregate scores were dichotomized into good and poor for knowledge, positive and negative for attitude scales, respectively. In this regard, the median (inter-quartile range) for attained knowledge score were 7 (6-8). So, a score below 7 was recoded as low and a score equal to or greater than 7 was considered high [20, 21]. Similarly, a score of $42(39-45)$ was used to stratify the sum of attitude scores on child faeces management into positive and negative categories, respectively. In constructing the wealth categories, variables such as ownership of the house, and household items such as fridge, Television/video, paid satellite television, care/motorcycle, laptop, separate room for kitchen contributed towards the measuring scale. The presence of the household items was rated ' 1 ' while the lack of these was rated ' 0 '. To stratify into categories, 1$39 \%, 40-69 \%$ and $\geq 70 \%$ were rated poor, average and rich, respectively. For bivariate analysis, chi-square (Pearson) statistics was used to assess the type of relationship among pairs of under five child defecation practice indices, except otherwise stated, with the level of significance at $<5 \%$.

\section{Multivariate analysis}

Following the guidance provided by Cronin et al., variables with a $p$-value of $<0.25$ in univariate analysis were included in the multivariate analyses model [22]. Variables with a $p$-value of $<0.05$ after backward elimination were retained in the final model.

\section{Outcome measures}

As suggested by Curtis et al., faeces disposal was recoded into a binary outcome, "safe" and "unsafe," depending on whether the practice is prone to faecal contamination of the environment [23]. In addition, handwashing was also dichotomized into 'correct' and 'incorrect' practice outcome while faeces management chain (involving faeces passage, transport, disposal, washing of faecal transport materials and hand hygiene) was stratified into 'safe' and 'unsafe' practice. ' 1 ' was assigned where all the attributes were safe while ' 0 ' was assigned to situations where any one step in the faeces management chain was not safe.

\section{Results}

\section{Socio-demographic and economic characteristics of respondents}

In the study, the average age (mean \pm Standard deviation) and monthly income (mode) were $30.8 \pm 7.5$ years and $10,000.00$ (\$28.60). Most caregivers were females (276, 92\%), and of Yoruba ethnicity (240, 80\%). Also, most caregivers were mothers of the under five children
(254, 84.7\%), had at least secondary education (216, $72.0 \%$ ) and were semi-skilled (171, 57.0\%) (Table 1). In addition, the study showed that Moreover, two-fifth of respondents $(124,41.3 \%)$ were rich while others belonged to the medium $(74,24.7 \%)$ and poor (102, $34.0 \%$ ) economic clusters, respectively (Table 2 ).

\section{Knowledge of caregivers on child defecation and hygiene indicators}

As shown in Table 3, 82\% (247) of respondents knew about the sanitary handling of faeces of under five children while only $32.3 \%$ (97) had knowledge that faeces of under five children can not be used on farms as manure without adequate treatment. Moreover, 36\% (109) respondents knew about correct handwashing process while about two-third respondents $(126,42 \%)$ knew about critical times for handwashing. The composite knowledge analysis, however, showed that six out of ten respondents $(192,64 \%)$ had good knowledge while $108(36 \%)$ had poor knowledge on assessed sanitation and hygiene indices.

\section{Attitude of respondents on child defecation and hygiene practices}

The findings of the study showed that 262 (87.3\%) respondents believed that the use of improved toilet is mandatory for safe management of faeces (SmoF) of under five children and only 38 (12.7\%) believed that the faeces of under five children is harmless when compared with those of adults. In addition, 283 (94.3\%) respondents believed that under five children should be potty trained, right from infancy, while $80 \%$ (240) believed that disposal of child's faeces on open dumps can cause faeco-oral diseases (Table 4). In the study, a little above average caregivers $(161,53.7 \%)$ had a positive attitude while $138(46.3 \%)$ had a negative attitude on sanitation and hygiene variables related to the management of child defecation practices.

\section{Child faeces management practices Water supply and sanitation access by caregivers of under five children}

In our study, most caregivers $(281,93.7 \%)$ had access to improved water sources, located outside their premises $(177,59.0 \%)$ with a modal travel time of five minutes for a return trip. Also, about two-thirds of caregivers (193, 64.3\%) had access to improved toilet facilities while others used unimproved $(70,23.3 \%)$ toilet or practiced open defecation $(36,12.0 \%)$. In addition, the toilets of 154 (51.3\%) caregivers were located outside their households premises and required a modal time of six minutes to use and/or disposed of the faeces passed by their under five children (Table 5). 
Table 1 Socio-demographic characteristics of caregivers of under five children

\begin{tabular}{|c|c|c|c|}
\hline Description of variables & Categories & Frequency & Percent \\
\hline \multirow[t]{2}{*}{ Age; years $(n=300)$} & $\leq 29$ & 156 & 52.0 \\
\hline & $\geq 30$ & 144 & 48.0 \\
\hline \multirow[t]{2}{*}{ Gender $(n=300)$} & Male & 24 & 8.0 \\
\hline & Female & 276 & 92.0 \\
\hline \multirow[t]{3}{*}{ Marital Status $(n=297)$} & Single & 17 & 5.7 \\
\hline & Married & 265 & 88.3 \\
\hline & $\begin{array}{l}\text { Divorced/separated/ } \\
\text { widow/er }\end{array}$ & 15 & 5.0 \\
\hline \multirow[t]{3}{*}{ Type of marriage $(n=292)$} & Polygamous & 61 & 20.3 \\
\hline & Monogamous & 215 & 71.7 \\
\hline & Single parenthood & 16 & 5.3 \\
\hline \multirow[t]{4}{*}{ Religion $(n=300)$} & Christianity & 205 & 68.3 \\
\hline & Islam & 84 & 28.0 \\
\hline & Traditional & 07 & 2.3 \\
\hline & Others & 04 & 1.3 \\
\hline \multirow[t]{4}{*}{ Ethnicity $(n=296)$} & Yoruba & 240 & 80.0 \\
\hline & Igbo & 44 & 14.7 \\
\hline & Hausa & 08 & 2.7 \\
\hline & Others & 04 & 1.3 \\
\hline \multirow{2}{*}{$\begin{array}{l}\text { No of under five children } \\
\text { caring for }(n=300)\end{array}$} & 1 under 5 child & 184 & 61.3 \\
\hline & $\begin{array}{l}\geq 2 \text { under } 5 \\
\text { children }\end{array}$ & 116 & 38.7 \\
\hline \multirow{2}{*}{$\begin{array}{l}\text { Relationship to under } \\
\text { five child }(n=280)\end{array}$} & Mother & 254 & 84.7 \\
\hline & Others & 26 & 8.7 \\
\hline \multirow{2}{*}{$\begin{array}{l}\text { No of household } \\
\text { members }(n=293)\end{array}$} & $\leq 4$ & 151 & 50.3 \\
\hline & $\geq 5$ & 142 & 47.3 \\
\hline \multirow{2}{*}{$\begin{array}{l}\text { Number of bedrooms } \\
\text { occupied (286) }\end{array}$} & $\leq 3$ & 261 & 87.0 \\
\hline & $\geq 4$ & 25 & 8.3 \\
\hline \multirow{4}{*}{$\begin{array}{l}\text { Respondents' highest } \\
\text { educational attainment } \\
(n=300)\end{array}$} & $\begin{array}{l}\text { No Formal } \\
\text { Education/Primary }\end{array}$ & 71 & 23.7 \\
\hline & Secondary & 116 & 38.7 \\
\hline & Tertiary & 100 & 33.3 \\
\hline & $\begin{array}{l}\text { Others (Quranic/ } \\
\text { vocational) }\end{array}$ & 13 & 4.3 \\
\hline \multirow{4}{*}{$\begin{array}{l}\text { Highest education of } \\
\text { respondents' spouse } \\
(n=300)\end{array}$} & $\begin{array}{l}\text { No Formal } \\
\text { Education/Primary }\end{array}$ & 61 & 20.3 \\
\hline & Secondary & 89 & 29.7 \\
\hline & Tertiary & 115 & 38.3 \\
\hline & $\begin{array}{l}\text { Others (Quaranic/ } \\
\text { vocational) }\end{array}$ & 35 & 11.7 \\
\hline \multirow{4}{*}{$\begin{array}{l}\text { Occupation of } \\
\text { respondents }(n=300)\end{array}$} & Business/Commerce & 43 & 14.3 \\
\hline & Civil Service & 48 & 16.0 \\
\hline & semi skilled & 171 & 57.0 \\
\hline & Others & 38 & 12.7 \\
\hline
\end{tabular}

Excreta management chain behaviour among caregivers of under five children

Defecation practices of under five children in the study area In the study, only 59 (19.7\%) households practiced safe faeces disposal during the day in contrast to 207 (69.0\%) that safely disposed of their children faeces at night (Table 5). In addition, the day and night preferences for under five children to pass faeces differs as shown in Fig. 1. The faeces passage arrangements in households of under five children showed that non -mobile (2, 0.7\%) and crawling $(16,5.3 \%)$ children passed faeces in diapers while the use of potty commenced with the crawling under five children. In the same manner, the use of a toilet, and possibly toilet training, starts with children that can walk unaided $(31,10.3 \%)$ while most caregivers use the potty for containment of faeces passed by their wards (Table 6). The study further showed that the potty is mostly used by 187 (63.2\%) caregivers during the day and 139 (36.5\%) caregivers at night while sanitary napkin is preferred by $32(10.8 \%)$ caregivers during the day and $39(13.0 \%)$ caregivers at night. However, defecation by under five children was done on the premises only by one in twenty caregivers $(14,4.7 \%)$ during the day (Fig. 1).

\section{Transport of faeces passed by under five children in the study area}

The potty was reported to be used for containment and transportation of the faeces of under five children by more than half of the respondents $(154,51.3 \%)$ while other transport devices included paper (16.7\%) and nylon (5.3\%) (Table 7). However, direct observation showed that caregivers used the shovel (27\%), simple household packer (25\%), bowl, broom and kettle (12\%) among others (Fig. 2).

\section{Disposal of faeces of under five children after passage and transportation}

Two-thirds of caregivers disposed of the faeces of their under five children in the toilet while the nearby bush/ open dumps were used by 49 (16.3\%) caregivers (Table 7). In addition, regarding the disposal of under five faeces, caregivers preferences varied with the mobility of under five children. The caregivers' disposal of faeces by 197 (65.7\%) under five children, especially those that walked unaided was done by rinsing and emptying into the toilet (Table 6). The study also showed that convenience (42\%), health (28\%) and cost (19\%) influenced the existing defecation practices by the caregivers for their under five children. Besides, the anal cleansing of children was done most times by rinsing with water (254, 84.7\%) and disposed of in the toilet by $54.3 \%$ caregivers (Table 7). 
Table 2 Economic indices of caregivers of under five children in the study area

\begin{tabular}{|c|c|c|c|c|}
\hline \multirow[t]{2}{*}{ Description of variables } & \multicolumn{2}{|l|}{ Yes } & \multicolumn{2}{|l|}{ No } \\
\hline & Frequency & Percent & Frequency & Percent \\
\hline Household owns residential building & 92 & 30.7 & 208 & 69.3 \\
\hline House built with blocks & 202 & 67.3 & 98 & 32.7 \\
\hline House floor cemented and/or tiled & 191 & 63.7 & 109 & 36.3 \\
\hline Household has a functional fridge/freezer & 155 & 51.7 & 145 & 48.3 \\
\hline Household has a functional TV/video sets & 219 & 73.0 & 81 & 27.0 \\
\hline Household subscribed to paid satellite TV receivers & 136 & 45.3 & 164 & 54.7 \\
\hline Household owns a car or motorcycle & 169 & 56.3 & 131 & 43.7 \\
\hline Household has a generator/desktop or laptop computer & 153 & 51.0 & 147 & 49.0 \\
\hline Household has separate room for kitchen & 207 & 69.0 & 93 & 31.0 \\
\hline Household uses gas/electric cooker/kerosine as the main cooking energy source & 208 & 69.3 & 92 & 30.7 \\
\hline Household shares bathroom/toilet with other households & 141 & 47.0 & 159 & 53.0 \\
\hline
\end{tabular}

Handling and safe keeping of faeces transportation and disposal tools

In our study, only 59 caregivers, corresponding to $19.7 \%$ had dedicated tools for removal of children faeces from where passed, for disposal (Fig. 3). The tools were washed after use by only 49 (16.3\%) caregivers with soap and water $(33,11 \%)$ and water only by $5.3 \%$ caregivers.

\section{Hand hygiene aftercare for under five children that passed faeces}

Most caregivers $(241,80.3 \%)$ washed their hands with soap after caring for under five children that passed faeces, while other behaviour ranged from washing hands with water only $(43,14.3 \%)$ to non-cleaning/washing of hands afterward by 6 (2\%) respondents. However, $94 \%$ of caregivers omitted at least one step in the process of ensuring SMoF.

\section{Period prevalence of selected childhood diseases}

The 2-week period-prevalence of childhood diseases, among under five children showed that diarrhoea was prevalent at $41(13.7 \%)$, followed by dysentery (7, 2.3\%), cholera $(5,1.7 \%)$ and helminthic worm infestation (4, $1.3 \%)$.

\section{Relationship among child defecation management and associated variables}

As shown in Tables 8 and 9, a significant association was found between handwashing practices and types of households toilets $(P<0.001)$, wealth $(P<0.001)$ defecation preferences of caregivers for under five children during the day $(P<0.001)$ and during the night $(P=0.008)$. In addition, knowledge was significantly associated with the types of households toilets $(P=0.037)$, faeces management chain $(P=0.032)$ and disposal of used anal cleaning materials $(P=0.002)$. In addition, diarrhoea was significantly associated with the day $(P=0.0001)$ and night $(P=0.0001)$ defecation practice by caregivers for under five children (Table 10). The odds of caregivers supported defecation of the under five children through improved toilet during the daytime, followed by handwashing were six times more than for those using the

Table 3 Knowledge of caregivers on selected child defecation and hygiene variables on child defecation management practices

\begin{tabular}{|c|c|c|c|c|}
\hline \multirow[t]{2}{*}{ Description of variables } & \multicolumn{2}{|c|}{ Correct response } & \multicolumn{2}{|c|}{ Incorrect response } \\
\hline & Frequency & Percent & Frequency & Percent \\
\hline Sanitary ways of handling the faeces of under five children $(n=300)$ & 247 & 82.3 & 53 & 17.7 \\
\hline Faeces of under five children could be used immediately as manure on farms $(n=300)$ & 203 & 67.7 & 97 & 32.3 \\
\hline Child training to safety defecate $(n=300)$ & 201 & 67.0 & 99 & 33.0 \\
\hline Correct process in hand washing $(n=300)$ & 109 & 36.3 & 191 & 63.7 \\
\hline Critical times when hands should be washed $(n=300)$ & 126 & 42.0 & 174 & 58.0 \\
\hline Times when under five children faeces should be safely disposed $(n=300)$ & 266 & 88.7 & 34 & 11.3 \\
\hline Location for safe keeping of child's potty $(n=300)$ & 189 & 63.0 & 111 & 37.0 \\
\hline Diseases associated with poor management of under five faeces $(n=300)$ & 261 & 87.0 & 39 & 13.0 \\
\hline With what should child potty be washed after use $(n=300)$ & 216 & 72.0 & 84 & 28.0 \\
\hline The faeces of under five children is harmless $(n=300)$ & 191 & 63.7 & 109 & 36.3 \\
\hline
\end{tabular}


Table 4 Attitude of respondents on sanitation and hygiene variables on child defecation practices

\begin{tabular}{|c|c|c|c|c|c|c|}
\hline \multirow[t]{2}{*}{ Description of variables } & \multicolumn{2}{|l|}{ Agree } & \multicolumn{2}{|l|}{ Uncertain } & \multicolumn{2}{|l|}{ Disagree } \\
\hline & Frequency & Percent & Frequency & Percent & Frequency & Percent \\
\hline $\begin{array}{l}\text { Improved toilet is not mandatory since under five children can defecate } \\
\text { in sanitary napkins and on soil }\end{array}$ & 26 & 8.7 & 12 & 4.0 & 262 & 87.3 \\
\hline Safe disposal of child faeces and maintaining hygiene after cleaning is tiring & 59 & 19.7 & 26 & 8.7 & 215 & 71.7 \\
\hline $\begin{array}{l}\text { The faeces of an under five child is not harmful when compared with } \\
\text { those of adults. }\end{array}$ & 38 & 12.7 & 31 & 10.3 & 231 & 77.0 \\
\hline Hand washing after handling child' faeces is not mandatory & 16 & 5.3 & 09 & 3.0 & 275 & 91.7 \\
\hline $\begin{array}{l}\text { Keeping the potty used for safe disposal of faeces by the under five } \\
\text { children to water sources is essential to clean it thoroughly }\end{array}$ & 55 & 18.3 & 18 & 6.0 & 227 & 75.7 \\
\hline $\begin{array}{l}\text { It is not mandatory to wash hands of under five children with soap } \\
\text { and water since child's anus has been washed. }\end{array}$ & 46 & 15.3 & 20 & 6.7 & 234 & 78.0 \\
\hline $\begin{array}{l}\text { Faeces passed by under five child should be disposed of immediately } \\
\text { after defecation }\end{array}$ & 283 & 94.3 & 03 & 1.0 & 14 & 4.7 \\
\hline Since infancy, under five children should be potty trained & 283 & 94.3 & 10 & 3.3 & 07 & 2.3 \\
\hline $\begin{array}{l}\text { Safe disposal of faeces passed by under five children could be achieved } \\
\text { even without ownership of improved household toilet }\end{array}$ & 144 & 48.0 & 32 & 10.7 & 124 & 41.3 \\
\hline $\begin{array}{l}\text { Buying potty is a waste of resources since the under five children can } \\
\text { defecate around the premises }\end{array}$ & 18 & 6.0 & 08 & 2.7 & 274 & 91.3 \\
\hline Disposing child's faeces on open dumps can lead to faeco-oral diseases & 240 & 80.0 & 33 & 11.0 & 27 & 9.0 \\
\hline
\end{tabular}

unimproved toilet, without handwashing. Also, most caregivers whose under five children practiced safe sanitation were rich $(p=0.009)$ (Table 8$)$. In addition, the odds of defecation by under five children through improved toilet at night, followed by handwashing were three-folds than the odds of those using unimproved toilet/open defecation for disposal of under five children faeces without washing hands afterward. In like manner, the odds of faeces management by caregivers for under five children older than two years was five folds likelihood than for those who were older (Table 9). Moreover, the odds of under five children whose faeces were disposed of by unsanitary methods had four-fold likelihood of developing diarrhoea (Table 10).

The result of the multivariate analysis predicting under five child faecal passage preferences during the day (Table 11) and at night (Table 12) was done through binary logistic regression. The significant predictors of where under five children passed excreta irrespective of time of the day were the caregiver's occupation (civil

Table 5 Description of water and sanitation facilities at households of respondents in the study area

\begin{tabular}{|c|c|c|c|}
\hline Description of variables & Category & Frequency & Percent \\
\hline \multirow[t]{2}{*}{ Classification of household water sources by improvement status $(n=298)$} & Improved water source & 281 & 93.7 \\
\hline & Unimproved water source & 17 & 5.7 \\
\hline \multirow[t]{2}{*}{ Distance of respondents' household to safe water sources $(n=300)$} & within the household premises & 123 & 41.0 \\
\hline & Outside the household premises & 177 & 59.0 \\
\hline Average distance of water sources from households $(n=300)$ & 5 min (mode) & & \\
\hline \multirow[t]{3}{*}{ Sanitation facilities at household level by safety status $(n=299)$} & Improved toilet & 193 & 64.3 \\
\hline & Unimproved toilet & 70 & 23.3 \\
\hline & Open Defecation & 36 & 12.0 \\
\hline \multirow[t]{2}{*}{ Distance of respondents' household to defecation facilities $(n=300)$} & within the household premises & 146 & 48.7 \\
\hline & Outside the household premises & 154 & 51.3 \\
\hline Average distance of households to toilet $(n=300)$ & $6 \min ($ mode) & & \\
\hline \multirow[t]{2}{*}{ Usual under five child defecation practice during the day $(n=300)$} & Safe point defecation practice & 59 & 19.7 \\
\hline & Unsafe point defecation practice & 241 & 80.3 \\
\hline \multirow[t]{2}{*}{ Usual under five child defecation practice at night $(n=300)$} & Safe point defecation practice & 207 & 69.0 \\
\hline & Unsafe point defecation practice & 93 & 31.0 \\
\hline
\end{tabular}




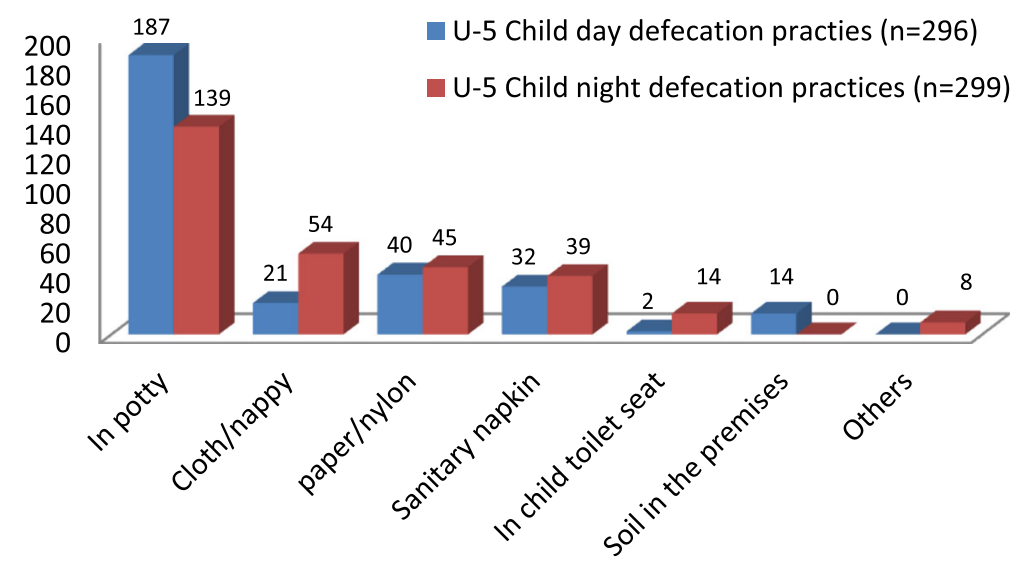

Fig. 1 Day and night defecation practices of under five children in the study area

servants), the age of index under five child, the transport and disposal of faeces whereas knowledge only predicts the passage of faeces preference by under five children at night $(P<0.05)$.

\section{Discussion}

The safe management of child faeces require not just a sound knowledge and awareness but also the provisions of child-friendly facilities in houses where care is provided as the basic minimum. To manage faeces of under five children, caregivers are required to know about, and be able to apply appropriate preventive behaviour within the socio-cultural beliefs and precepts to promote public health. The study, therefore, explored faeces management practices of under five children in an ancient city in Nigeria, among caregivers who were ethnically and chronologically similar in socio-demographic characteristics but differentiated on their prevailing knowledge, attitudes, and practices.

\section{Knowledge of caregivers on defecation practices among under five children}

Knowledge empowers when allowed to influence our attitudes and practices [24]. Many caregivers knew about the sanitary handling of faeces of under five children, correct handwashing practices and critical times when hand washing should be performed. The study identified two clusters of caregivers; those with low and high knowledge and attitudes. In our study, more than half caregivers had good knowledge and positive attitudes in contrast to the findings of Demberere et al., among mothers of under-five children in Mawabeni in Zimbabwe where they had poor knowledge and attitudes [25].

Table 6 Faeces of under five children passage and disposal practices during the last defecation episodes in the study area

\begin{tabular}{|c|c|c|c|c|c|c|}
\hline Variables description & Categories & $\begin{array}{l}\text { Non-crawling } \\
(\%)\end{array}$ & $\begin{array}{l}\text { Crawling } \\
(\%)\end{array}$ & $\begin{array}{l}\text { Assisted } \\
\text { walking (\%) }\end{array}$ & $\begin{array}{l}\text { Walking } \\
\text { unaided (\%) }\end{array}$ & $\begin{array}{l}\text { Total } \\
(\%)\end{array}$ \\
\hline \multirow{7}{*}{$\begin{array}{l}\text { Where were the faeces of under five children passed } \\
\text { during the last defecation episode }(n=300)\end{array}$} & Toilet & - & - & - & $31(10.3)$ & 31 \\
\hline & Nappy & $02(0.7)$ & $16(5.3)$ & $12(4.0)$ & $11(3.7)$ & 41 \\
\hline & Potty & - & $03(1.0)$ & $23(7.7)$ & $152(51.3)$ & 178 \\
\hline & Nylon & - & - & $01(0.3)$ & $05(1.7)$ & 06 \\
\hline & Paper & - & $01(0.3)$ & $01(0.3)$ & $30(10.0)$ & 32 \\
\hline & Soil/ground premises & - & - & $04(1.3)$ & $08(2.6)$ & 12 \\
\hline & Total & $02(0.7)$ & $20(6.6)$ & $41(13.6)$ & $237(79.6)$ & 300 \\
\hline \multirow{6}{*}{$\begin{array}{l}\text { Where were the faeces of under five children disposed } \\
\text { during the last defecation episode }(n-288)\end{array}$} & Rinse/emptied in the toilet & - & $06(2.0)$ & $28(9.3)$ & $197(65.7)$ & 231 \\
\hline & Disposed with solid waste & $01(0.3)$ & $12(4.0)$ & $08(2.7)$ & $24(8.0)$ & 45 \\
\hline & Buried in the premises & - & $01(0.3)$ & - & $01(0.3)$ & 02 \\
\hline & $\begin{array}{l}\text { Dilluted \&spread in the } \\
\text { premises }\end{array}$ & $01(0.3)$ & $02(0.7)$ & $01(0.3)$ & $02(0.7)$ & 06 \\
\hline & Left in the open & - & - & $01(0.3)$ & $03(1.0)$ & 04 \\
\hline & Total & $02(0.7)$ & $41(7.0)$ & $38(12.6)$ & $227(75.7)$ & 288 \\
\hline
\end{tabular}


Table 7 Management of faeces passed by under five children by their caregivers

\begin{tabular}{|c|c|c|c|}
\hline Description of variables & Category & Frequency & Percent \\
\hline \multirow{4}{*}{$\begin{array}{l}\text { Transportation of child } \\
\text { faeces }(n=279)\end{array}$} & A potty & 154 & 51.3 \\
\hline & Not applicable & 59 & 19.7 \\
\hline & Paper & 50 & 16.7 \\
\hline & Nylon & 16 & 5.3 \\
\hline \multirow{5}{*}{$\begin{array}{l}\text { Routine disposal option } \\
\text { of child faeces }(n=280)\end{array}$} & Latrine/toilet & 201 & 67.0 \\
\hline & $\begin{array}{l}\text { In nearby bush/open } \\
\text { dump }\end{array}$ & 49 & 16.3 \\
\hline & $\begin{array}{l}\text { In the household solid } \\
\text { waste receptacle }\end{array}$ & 23 & 7.7 \\
\hline & Open drainage & 5 & 1.7 \\
\hline & $\begin{array}{l}\text { Left in the open in } \\
\text { the compound }\end{array}$ & 2 & .7 \\
\hline \multirow{5}{*}{$\begin{array}{l}\text { How child anus was } \\
\text { cleaned after defecation } \\
(n=299)\end{array}$} & Rinsed with water & 254 & 84.7 \\
\hline & Tissue paper/paper & 21 & 7.0 \\
\hline & Paper & 11 & 3.7 \\
\hline & $\begin{array}{l}\text { Wipe with a clean } \\
\text { section of soiled } \\
\text { nappy/sanitary napkin }\end{array}$ & 10 & 3.3 \\
\hline & Others & 03 & 0.9 \\
\hline \multirow{5}{*}{$\begin{array}{l}\text { How under five child } \\
\text { cleaning materials was } \\
\text { disposed of after use } \\
(n=297)\end{array}$} & In toilet & 163 & 54.3 \\
\hline & $\begin{array}{l}\text { Cleaning water } \\
\text { emptied in the } \\
\text { environment }\end{array}$ & 48 & 16.0 \\
\hline & $\begin{array}{l}\text { Solid material } \\
\text { disposed of in open } \\
\text { dump }\end{array}$ & 45 & 15.0 \\
\hline & $\begin{array}{l}\text { Disposed with } \\
\text { domestic solid waste }\end{array}$ & 29 & 9.7 \\
\hline & $\begin{array}{l}\text { No specific disposal } \\
\text { method }\end{array}$ & 12 & 4.0 \\
\hline \multirow{2}{*}{$\begin{array}{l}\text { Household own tool to } \\
\text { manage child faeces } \\
(n=300)\end{array}$} & Yes & 59 & 19.7 \\
\hline & No & 241 & 80.3 \\
\hline \multirow{2}{*}{$\begin{array}{l}\text { Faeces management } \\
\text { tools washed after use? } \\
(n=241)\end{array}$} & Yes & 49 & 16.3 \\
\hline & No & 11 & 3.7 \\
\hline \multirow{2}{*}{$\begin{array}{l}\text { Materials used in washing } \\
\text { the faeces management } \\
\text { tools }(n=49)\end{array}$} & Soap and water & 33 & 11.0 \\
\hline & Water only & 16 & 5.3 \\
\hline \multirow{4}{*}{$\begin{array}{l}\text { Hand hygiene practices by } \\
\text { caregivers after contact } \\
\text { with under five child } \\
\text { faeces }(n=299)\end{array}$} & $\begin{array}{l}\text { Wash hands with } \\
\text { water and soap }\end{array}$ & 241 & 80.3 \\
\hline & $\begin{array}{l}\text { Wash hands with } \\
\text { water only }\end{array}$ & 43 & 14.3 \\
\hline & $\begin{array}{l}\text { Clean hands with } \\
\text { rag only }\end{array}$ & 09 & 3.0 \\
\hline & $\begin{array}{l}\text { Do not clean/wash } \\
\text { hands after caring for } \\
\text { the child }\end{array}$ & 06 & 2.0 \\
\hline
\end{tabular}

\section{Attitudes of caregivers on defecation practices among} under five children

Positive attitude indicates the presence of the right dispositions on the behaviour that could aid sanitary management of child faeces. In our study, most caregivers thought the faeces of under five children was not as harmful as those of adults, in agreement with the findings of Bain and Luyendijk; Brown, Cairncross and Ensick and Gil et al. [14, 26, 27]. This contrasted with the situation in reality, where the faeces of under five children contains a higher number and diversity of pathogens [22]. In addition, only a little more than half of the respondents had a positive attitude and barring other confounders, will ensure that caregivers practice SMoF passed by the under five children, though the proportion that practiced SMoF of under five children could not confer herd immunity on other children in the study area. This is a concern for intervention since a positive attitude is a pre-requisite to safe behavioural change in the population, based on the explanations by Lanata et al. [8], that faeces of young children predominates in the environment where their peers are exposed and vulnerable to faeces related childhood illnesses. To avoid this situation. a positive attitude by caregivers during the formative years of the under five children are required to model their behaviour towards safe excreta management and hygiene practices.

\section{Access to water, sanitation and hygiene facilities in caregivers households}

The importance of adequate and safe water to improved sanitation and hygiene practice has been discussed by authors $[10,28]$ and also in Burkina Faso by Curtis et al. [23] and in India by Sahay et al. [29], where access to water within the premises was associated with safe child faeces disposal. In this study, many caregivers had access to improved water supply, though located outside their premises which required about five minutes of travel time for a return trip, an additional burden on their numerous responsibilities. Therefore, limited availability of water within the premises of a few respondents, made it challenging to abide by best practices for child faeces management. Availability of safe water, within the households premises, enhances the caregivers' ability to practice handwashing. Inadequate handwashing predisposes under five children to childhood diseases, probably through 'make-shift' arrangements, in agreement with the findings of Freeman et al. [30]. The above situation might be made worse by the lack of child-friendly facilities at the household level, to enable safe child defecation. Moreover, informal interaction with some caregivers revealed that the health promotion by nurses with pregnant women during antenatal visits excluded 


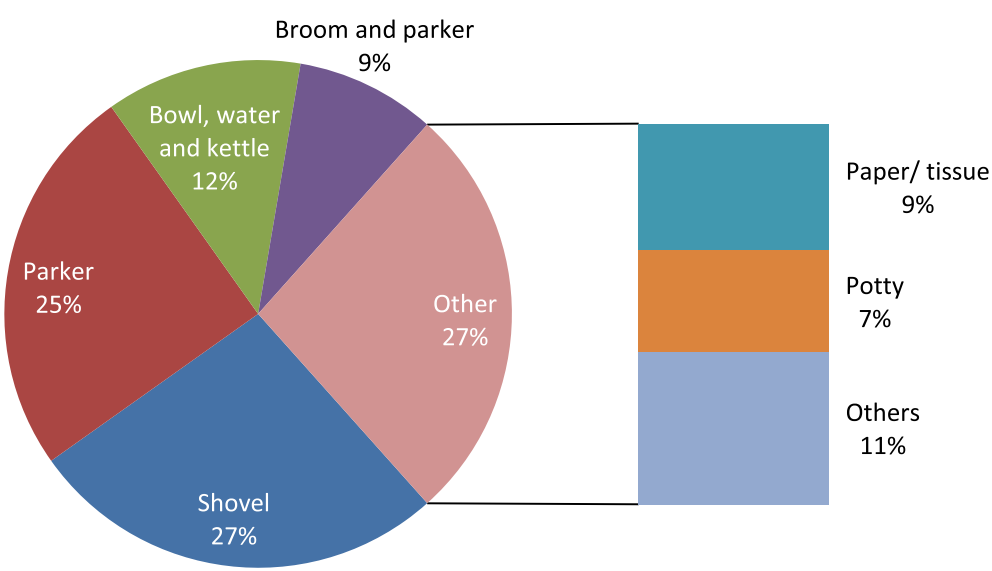

Fig. 2 Faecal transportation processes for under five chidren

the information on $\mathrm{SMoF}$ for under five children, despite its associated risks.

In this study, about two-thirds of the caregivers had improved toilet facilities which should influence the health status of under five children., in agreement with

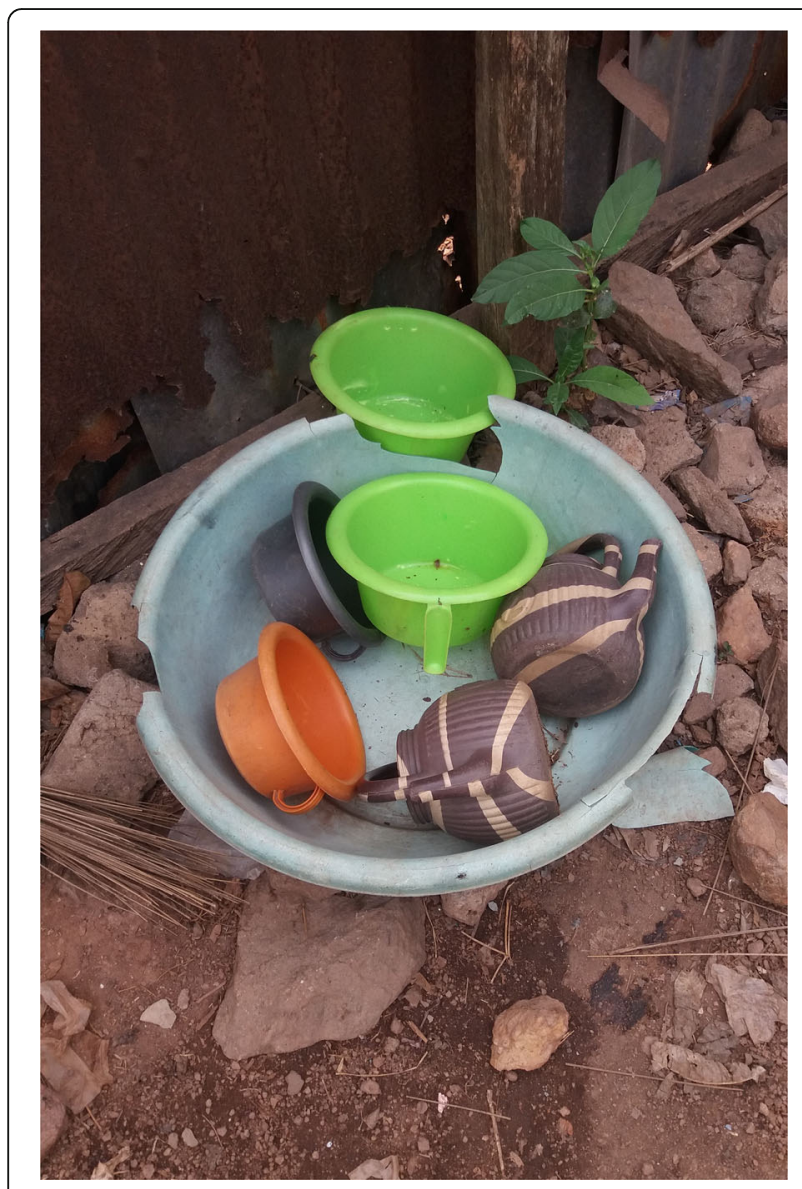

Fig. 3 A receptacle for potties and anal cleansing water containers in the study area
Mosley and Chen [31] framework, which saw sanitation as a proximate determinant of child health and acknowledged its importance in providing a hygienic environment to the growing child.

\section{Under five faeces management practices by caregivers}

According to World Bank/Unicef [10], pre-ambulatory under five children may not be able to use any toilet facility because of their age, stage of physical development and safety concerns irrespective of toilet access. This was in agreement with the findings in our study where about two-thirds of caregivers had access to improved toilet facilities whereas 19.7 and $69.0 \%$ among the under five children practiced safe defecation during the daytime and at night, respectively, in contrast to higher access to safe toilet facilities by the caregivers. The above findings were also in agreement with those of Demberere et al. [32] where $17 \%$ caregivers practiced safe disposal of children's faeces and with the findings of Miller-Petrie et al. [33] where 'child faeces are disposed of unsafely even among households with latrines' Besides, the six minutes of travel time to use and disposed of child's faeces, outside the households premises contributed to the prevailing poor disposal practice.

There is a direct relationship between the age of the under five children and where they passed faeces, probably as the children age, they either learn about toilet discipline by the use of potty (Fig. 3) or disliked the sight of faeces. Moreover, the potty is used most of the time for the containment and transportation of children excreta, especially where the child has learned the habit of using the potty in defecation. Besides, the use of unsanitary transport media for faeces could predispose young children to enteric infection since they are mostly exposed to the ambient agents due to the time they spend roaming the environment and their habit of putting fingers 
Table 8 Relationship between socio-demographic by the management of under five children faeces variables in the study area

\begin{tabular}{|c|c|c|c|c|}
\hline Variables & Categories & \multicolumn{3}{|c|}{ Sanitation chain by caregivers for under- 5 children during the day } \\
\hline \multirow[t]{6}{*}{ Wealth categories } & & Unsafe & Safe & Total \\
\hline & Poor & $97(95.1 \%)$ & $5(4.9 \%)$ & $102(34.0 \%)$ \\
\hline & Average & $72(97.3 \%)$ & $2(2.7 \%)$ & $74(24.7 \%)$ \\
\hline & Rich & $114(91.9 \%)$ & $10(8.1 \%)$ & $124(41.3 \%)$ \\
\hline & Total & $283(94.3 \%)$ & $17(5.7 \%)$ & $300(100.0 \%)$ \\
\hline & \multicolumn{4}{|c|}{ Chi square $(X)=2.797$; degree of freedom $(\mathrm{d} f)=2, P$-value $(P)=0.247^{\mathrm{a}}$} \\
\hline \multirow[t]{8}{*}{ Wealth categories } & & \multicolumn{3}{|c|}{ Sanitation chain by caregivers for under- 5 children at night } \\
\hline & & Unsafe & Safe & Total \\
\hline & Poor & $49(48.0 \%)$ & $53(52.0 \%)$ & $102(34.0 \%)$ \\
\hline & Average & $18(24.3 \%)$ & $5675.7 \%)$ & $74(24.7 \%)$ \\
\hline & Rich & $26(21.0 \%)$ & $98(79.0 \%)$ & $124(41.3 \%)$ \\
\hline & Total & $93(31.0 \%)$ & $207(69.0 \%)$ & $300(100.0 \%)$ \\
\hline & \multicolumn{4}{|c|}{$x=21.221 ; \mathrm{df}=2, P=0.0001$} \\
\hline & & \multicolumn{3}{|c|}{ Handwashing practices } \\
\hline Variable & Category & Correct & Incorrect & Total \\
\hline \multirow[t]{4}{*}{ Types of household toilet } & improved & 87 (79.8\%) & $106(56.1 \%)$ & $193(64.8 \%)$ \\
\hline & Unimproved & $22(20.2 \%)$ & $83(43.9 \%)$ & $105(35.2 \%)$ \\
\hline & Total & $109(36.6 \%)$ & $189(63.4 \%)$ & $298(100.0 \%)$ \\
\hline & \multicolumn{4}{|c|}{$X=17.062 ; \mathrm{df}=1 ; P<.0001 ;$ Odd ratio $(\mathrm{OR})=0.323 ;$ Confidence interval $(C \mathrm{Cl})=0.187-0.559$} \\
\hline \multirow[t]{5}{*}{ Wealth } & Poor & $13(12.7 \%)$ & $89(87.3 \%)$ & $102(34.1 \%)$ \\
\hline & Average & $19(25.7 \%)$ & $55(74.3 \%)$ & $74(24.7 \%)$ \\
\hline & Rich & $77(62.6 \%)$ & $46(37.4 \%)$ & $123(41.1 \%)$ \\
\hline & Total & $109(36.5 \%)$ & $190(63.5 \%)$ & $299(100.0 \%)$ \\
\hline & \multicolumn{4}{|c|}{$X=64.764 ; \mathrm{df}=2 ; P<0.0001$} \\
\hline \multirow[t]{4}{*}{ Defecation practice of the under 5 child during the day } & Improved & $101(40.6 \%)$ & $148(59.4 \%)$ & $249(84.4 \%)$ \\
\hline & Unimproved & $5(10.9 \%)$ & $41(89.1 \%)$ & $46(15.6 \%)$ \\
\hline & Total & $106(35.9 \%)$ & $189(64.1 \%)$ & $295(100.0 \%)$ \\
\hline & \multicolumn{4}{|c|}{$X==14.870 ; \mathrm{df}=1 ; P<.0001^{\mathrm{a}} ; \mathrm{OR}=5.596 ; C l=2.138-14.648$} \\
\hline \multirow[t]{4}{*}{ Defecation practice of the under 5 child during the night } & Improved & $100(39.7 \%)$ & $152(60.3 \%)$ & $252(84.3 \%)$ \\
\hline & Unimproved & 9 (19.1\%) & 38 (80.9\%) & $47(15.7 \%)$ \\
\hline & Total & $109(36.5 \%)$ & $190(63.5 \%)$ & $299(100.0 \%)$ \\
\hline & \multicolumn{4}{|c|}{$X=7.210, d f=1, P=.008^{a} ; O R=2.778 ; C l=1.287-5.994$} \\
\hline
\end{tabular}

${ }^{a}=$ Fisher's Exact Test

and fomites in their mouths $[34,35]$. Hence, caregivers should be knowledgeable about the dangers associated with allowing 'convenience' to determine the passage, transport, and disposal of faeces passed by the under five children.

In most cases, the use of tools dedicated to the management of under five child faeces was not considered important by caregivers in the study area. This should be improved to ensure that child faeces is being safely managed to improve their health and livelihood.
Washing the tools after every use with soap and water was good, assisted by the presence of water, sanitation and hygiene facilities in the home environment.

In the study, hand hygiene was practiced by most caregivers with soap after caring for their ch children. This is good though the importance of sustainable hand washing at critical times by caregivers and for their under five children should be advocated for, more so when very few caregivers practiced SMoF. in the care of their under five children. 
Table 9 Relationship between knowledge and selected variables on under five children defecation practices

\begin{tabular}{|c|c|c|c|c|}
\hline \multirow[t]{2}{*}{ Variables } & \multirow[t]{2}{*}{ Categories } & \multicolumn{3}{|l|}{ Knowledge } \\
\hline & & Low & High & Total \\
\hline \multirow[t]{4}{*}{ Types of household toilet } & Improved & $78(72.2 \%)$ & $115(60.2 \%)$ & $193(64.5 \%)$ \\
\hline & Unimproved & $30(27.8 \%)$ & $76(39.8 \%)$ & $106(35.5 \%)$ \\
\hline & Total & $108(36.1 \%)$ & $191(63.9 \%)$ & $299(100.0 \%)$ \\
\hline & \multicolumn{4}{|c|}{ Chi square $(X)=4.351$; degree of freedom $(d f)=1, P=0.037 ; O R=0.582 ; C l=0.349-0.970$} \\
\hline \multirow{4}{*}{$\begin{array}{l}\text { Under five faeces management chain } \\
\text { during the day the caregiver }\end{array}$} & Unsafe & $98(34.6 \%)$ & $185(65.4 \%)$ & $283(94.3 \%)$ \\
\hline & Safe & $10(58.8 \%)$ & $7(41.2 \%)$ & $17(5.7 \%)$ \\
\hline & Total & $108(36.0 \%)$ & $192(64.0 \%)$ & $300(100.0 \%)$ \\
\hline & \multicolumn{4}{|c|}{$X=4.074 ; \mathrm{df}=1, P=0.044 ; \mathrm{OR}=0.371 ; \mathrm{Cl}=0.137-1.004$} \\
\hline \multirow{4}{*}{$\begin{array}{l}\text { Under five faeces management chain by } \\
\text { caregiver at night }\end{array}$} & Unsafe & $71(40.3 \%)$ & $105(59.7 \%)$ & $176(58.7 \%)$ \\
\hline & Safe & $37(29.8 \%)$ & $87(70.2 \%)$ & $124(41.3 \%)$ \\
\hline & Total & $108(36.0 \%)$ & $192(64.0 \%)$ & $300(100.0 \%)$ \\
\hline & \multicolumn{4}{|c|}{$X=3.483 ; d f=1, P=0.062 ; O R=1.590 ; C l=0.975-02.592$} \\
\hline \multirow{4}{*}{$\begin{array}{l}\text { Disposal of the anal cleansing materials } \\
\text { of under five children }\end{array}$} & Safe disposal & $46(28.2 \%)$ & $117(71.8 \%)$ & $163(54.9 \%)$ \\
\hline & Unsafe disposal & $61(45.5 \%)$ & $73(54.5 \%)$ & $134(45.1 \%)$ \\
\hline & Total & $107(36.0 \%)$ & $190(64.0 \%)$ & $297(100.0 \%)$ \\
\hline & \multicolumn{4}{|c|}{$X=9.552 ; d f=1, P=0.002 ; O R=0.471 ; C l=0.291-0,762$} \\
\hline
\end{tabular}

\section{Diarrhoea prevalence among under five children}

Evidence from the works of Traore et al. and MillerPetrie et al. [33, 35], confirmed that the presence of faeces, especially those of under five children in the premises has been found to be associated with diarrhoea and hospital admissions. Also, children are at a greater risk of diarrhoea if their caregivers disposed of their faeces in an insanitary manner according to Baltazar and Solon [36]. The above studies were in agreement with the findings in our study where under five children whose caregivers guided them on safe passage of faeces had a lesser risk of having diarrhoea. The presence of faeces in the premises of the under five children could be responsible for the high period prevalence of diarrhoea in the study, though the finding should be interpreted with caution as a result of seasonal variations in the prevalence of diarrhoea [4]. The study finding where handwashing was positively associated with ownership of improved toilet was also in agreement with that of Azage and Haile and Majorin et al. [37, 38], where handwashing was positively associated with household toilet ownership, wealth; day, and defecation practices of under five children at night while knowledge influences household toilet, composite faeces management chain and disposal of anal cleaning materials used to clean up under five children by their caregivers after defecation.

\section{Strengths and weaknesses of the study}

The study is a population-based, exploratory and crosssectional in design with the respondents randomly selected through multi-stage sampling technique in order to reflect their true characteristics. Hence, the findings can be generalised to the study population,

Table 10 Relationship between daytime defecation practices and diarrhoea prevalence in the study area

\begin{tabular}{|c|c|c|c|c|}
\hline \multirow[t]{2}{*}{ Variables } & \multirow[t]{2}{*}{ Categories } & \multicolumn{3}{|l|}{ Diarrhoea } \\
\hline & & No & Yes & Total \\
\hline \multirow[t]{4}{*}{ Defecation practice during the day } & Unsafe & $217(90.4 \%)$ & $23(9.6 \%)$ & $240(80.3 \%)$ \\
\hline & Safe & $41(69.5 \%)$ & $18(30.5 \%)$ & $59(19.7 \%)$ \\
\hline & Total & $258(86.3 \%)$ & $41(13.7 \%)$ & $299(100.0 \%)$ \\
\hline & \multicolumn{4}{|c|}{ Chi square $(X)=7.525$; degree of freedom $(d f)=1, P=0.0001 ; O R=4.142 \mathrm{Cl}=2.054-8.352$} \\
\hline \multirow[t]{4}{*}{ Defecation practice during the day } & Unsafe & $68(73.1 \%)$ & $25(26.9 \%)$ & $93(31.0 \%)$ \\
\hline & Safe & 191 (92.3\%) & 16 (7.7\%) & 207 (69.0\%) \\
\hline & Total & 259 (86.3\%) & 41 (13.7\%) & $300(100.0 \%)$ \\
\hline & \multicolumn{4}{|c|}{ Chi square $(X)=19.949 ; d f=1, P=0.0001 ; O R=0.228 ; C l=115-0,452$. } \\
\hline
\end{tabular}


Table 11 Multivariate regression of variables predicting defecation passage preferences during the day for under five children by their caregivers

\begin{tabular}{|c|c|c|c|}
\hline Factor & $\begin{array}{l}\text { Odd ratio } \\
\text { (OR) }\end{array}$ & $\begin{array}{l}95 \% \text { confidence } \\
\text { interval (Cl) }\end{array}$ & $P$-value \\
\hline \multicolumn{4}{|l|}{ Education } \\
\hline None - Primary & 1.920 & $0.793-4.646$ & 0.148 \\
\hline Secondary and above & Ref & & \\
\hline \multicolumn{4}{|l|}{ Occupation } \\
\hline Civil Servant & 3.105 & $1.050-9.181$ & 0.041 \\
\hline Other (semi-skilled/business) & Ref & & \\
\hline \multicolumn{4}{|l|}{ Age of index Under five children } \\
\hline $3-5$ years & 5.922 & $2.422-14.476$ & 0.001 \\
\hline $1-2$ years & Ref & & \\
\hline \multicolumn{4}{|l|}{ No. of Under five children } \\
\hline$>2$ & 4.774 & $0.329-69.215$ & 0.252 \\
\hline $1-2$ & Ref & & \\
\hline \multicolumn{4}{|c|}{ Relationship of caregiver to the under-5 children } \\
\hline Mother & 1.568 & $0.545-4.509$ & 0.404 \\
\hline Others (grandmother/paid carer) & Ref & & \\
\hline \multicolumn{4}{|c|}{ Location of the household toilet to the residence } \\
\hline Outside the premises & 1.954 & $0.819-4.660$ & 0.131 \\
\hline Within the premises & Ref & & \\
\hline \multicolumn{4}{|l|}{ Knowledge } \\
\hline Poor & 2.326 & $0.993-5.446$ & 0.052 \\
\hline Good & Ref & & \\
\hline \multicolumn{4}{|l|}{ Transport of faeces } \\
\hline Unsafe & 7.804 & $3.222-18.899$ & 0.001 \\
\hline Safe & Ref & & \\
\hline \multicolumn{4}{|l|}{ Disposal of faeces } \\
\hline Unsafe & 2.593 & $1.126-5.969$ & 0.025 \\
\hline Safe & Ref & & \\
\hline \multicolumn{4}{|l|}{ Handwashing process } \\
\hline Incorrect & 1.504 & $0.587-3.851$ & 0.395 \\
\hline Correct & Ref & & \\
\hline
\end{tabular}

especially in southwest Nigeria. One of the weaknesses of the study is that the data is partly dependent on self-reported information from caregivers of under five children. Though non-response persists in the data, conscious efforts were made to minimize it during data collection by engaging experienced enumerators, skilled in the art of data collection at the population level. However, causal effects can't be adequately measured while disease prevalence was based on period prevalence, as at the time of the study, of course, which did not take into cognizance seasonal fluctuations which are time dependent.
Table 12 Multivariate regression of variables predicting defecation passage preferences at night for under five children by their caregivers

\begin{tabular}{|c|c|c|c|}
\hline Factor & $\begin{array}{l}\text { Odd ratio } \\
\text { (OR) }\end{array}$ & $\begin{array}{l}95 \% \text { confidence } \\
\text { interval (Cl) }\end{array}$ & $P$-value \\
\hline \multicolumn{4}{|l|}{ Education } \\
\hline Secondary and above & 1.580 & $0.784-3.185$ & 0.201 \\
\hline None - Primary & Ref & & \\
\hline \multicolumn{4}{|l|}{ Occupation } \\
\hline Civil Servant & 2.896 & $1.059-7.919$ & 0.038 \\
\hline Other (semi-skilled/business) & Ref & & \\
\hline \multicolumn{4}{|l|}{ Age of index Under five children } \\
\hline $1-2$ years & 1.385 & $0.763-2.517$ & 0.284 \\
\hline $3-5$ years & Ref & & \\
\hline \multicolumn{4}{|l|}{ No. of Under five children } \\
\hline$>2$ & 1.970 & $0.401-9.680$ & 0.404 \\
\hline $1-2$ & Ref & & \\
\hline
\end{tabular}

Relationship of caregiver to the under five children

\begin{tabular}{llll} 
Mother & 1.078 & $0.495-2.350$ & 0.850 \\
Others (grandmother/paid carer) & Ref & & \\
Location of the household toilet to the residence & & \\
Within the premises & 1.630 & $0.842-3.154$ & 0.147 \\
Outside the premises & Ref & & \\
Knowledge & & & 0.001 \\
Good & 3.495 & $1.802-6.780$ & \\
Poor & Ref & & \\
Transport of faeces & & & \\
Safe & 2.250 & $1.092-4.640$ & \\
Unsafe & Ref & & \\
Disposal of faeces & & & \\
Safe & 2.316 & $1.165-4.605$ & 0.017 \\
Unsafe & Ref & & \\
Handwashing process & & & \\
Incorrect & 1.298 & $0.649-2.595$ & \\
Correct & Ref & & \\
\hline & & & \\
\hline
\end{tabular}

\section{Conclusions}

The good knowledge and positive attitude showed by caregivers were at variance with practice while the factors that predicted where under five children defecate during the day were, included where the child' anal cleaning materials were disposed, the distance to the toilet facility to the residence and caregivers education. Hence, policy re-orientation, development of appropriate behavioural change communication guidelines should be developed into packages to address observed negative practices, mainstreamed and promoted through appropriate communication channels in Nigeria. 


\section{Additional file}

Additional file 1: Questionnaire on excreta management practices and diarrhoeal illnesses among under-five children in lle Ife, Osun state, southwet Nigeria. The file contained the validated questionnaire used for data collection in the study area. (DOCX $55 \mathrm{~kb}$ )

\section{Abbreviations}

JMP: Joint monitoring programme; LGAs: Local government areas; OD: Open defecation; SMoF: Safe management of faeces

\section{Acknowledgements}

The authors express gratitude to the respondents who were caregivers of under five children for their time and participation in the study during the field data collection exercise. In addition, the authors appreciates the immeasurable support, mentoring and guidance provided by Professor Emily Christensen Rand on this study since project conception, to proof reading the manuscript drafts. Moreover, we thank Dr. (Mrs.) Oluwaseun Esan for the detailed, professional and grammatical reviews which improved the sequencing and readability of the manuscript. On a final note, we thank the peer reviewers for their constructive suggestions and comments that helped in making the manuscript better than when first submitted for peer review.

\section{Funding}

No funding was obtained for this study.

\section{Availability of data and materials}

The dataset analyzed during the current study is available from the corresponding author on reasonable request.

\section{Authors' contributions}

AlOO conceived the study and coordinated the study design, participated in data analysis and supported ATO in constructing the summary tables, coordinated and finalised the first draft and coordinated reviews of the manuscript prior to submission; ATO co-designed the study, coordinated data analyis, constructed the summary tables and critiqued the various drafts of the manuscript; OEA co-designed the study, supervised field data collection, contributed to data entry and analysis and wrote the introduction part of the manuscript; AAD co-designed the study, co-supervised data collection and entry and wrote the first draft of the method section; OSO co-designed the study, co-supervised field data collection and wrote the first draft of the results; AbOO co-designed the study, co-supervised data collection, participated in data entry and analysis and wrote the first draft of the discussion. All the authors reviewed and approved the first and final drafts of the manuscript prior to submission to BMC Public Health for peer- review.

\section{Competing interests}

The authors declare that they have no competing interests.

\section{Consent for publication}

Not applicable.

\section{Ethics and consent to participate}

The study protocol was approved by the Ethical Committee of the Institute of Public Health of the Obafemi Awolowo University in Nigeria. Prior to respondents' consent, they were briefed about the purpose of the study and were informed that participation was voluntary and refusal to participate attracts no penalty. In this study, written informed consent was obtained from all consented respondents. Personal identifiers were removed in the data to ensure confidentiality. Only the research team members had access to electronic data, encrypted and stored only on the external hard drive of the principal investigator.

\section{Study design}

The study utilized the exploratory cross-sectional design among caregivers of under-five children in Ile-Ife, Southwest Nigeria.

Received: 8 July 2016 Accepted: 25 January 2017

Published online: 08 February 2017

\section{References}

1. United Nations-Water Decade Programme on Advocacy and Communication and WSSCC. The Human Right to Water and Sanitation. http://www.un.org/waterforlifedecade/pdf/human_right_to_water_and_ sanitation_media_brief.pdf. Accessed 1 June 2016.

2. Bartram J, Cairncross S. Forgotten foundations of health. PLoS Med. 2010; 7(11):e1000367.

3. Jenkins, MW, Cumming, O, Scott, B, and Cairncross, S. Beyond 'improved' towards 'safe and sustainable' urban sanitation: assessing the design, management, and functionality of sanitation in poor communities of Dar es Salaam, Tanzania. J Water Sanit Hyg Dev. 2014;4(1):131-41.

4. National Population Commission (NPC) [Nigeria] and ICF International. Nigeria demographic and health survey 2013. Abuja, Nigeria, and Rockville, Maryland, USA: NPC and ICF International; 2014. p. 566.

5. WHO/Unicef. Progress on drinking water and sanitation-2015 update. The World Health Organization: Geneva; 2015. Accessed 16 Feb 2016.

6. Fawole A. One incredibly healthy body: indivisible and intricately linked to self and society. 9th Annual Professor Grillo memorial lecture. Ile-lfe: College of Health Sciences, Obafemi Awolowo University; 2016. p. 46.

7. Danquah L, Mensah CM, Agyemang S, Awuah E. Risk factors associated with diarrhea morbidity among children younger than five years in the Atwima Nwabiagya District, Ghana: a cross-sectional study. Sci J Pub Health. 2015;3(3):344-52

8. Lanata CF, Huttly SRA, Yeager BA. Diarrhea: whose feces matter? Reflections from studies in a Peruvian shanty town. Pediatr Infect Dis J. 1998;17:7-9.

9. Kwong LH, Ercumen A, Pickering AJ, Unicomb L, Davies J, Luby SP. Hands- and object-mouthing of rural Bangladeshi children 3-18 months old. Int J Environ Res Public Health. 2016;13:563. doi:10.3390/ ijerph13060563.

10. World Bank/Unicef. Child feces disposal in Nigeria. 2015. Water and Sanitation Program, 4 pages

11. Feachem R, Bradley D, Garelick H, Mara D. Sanitation and disease: health aspects of wastewater and excreta management. Chichester: John Wiley \& Sons; 1983.

12. World Bank/Unicef. Management of child feces: current disposal practices. scaling up rural sanitation and hygiene. water and sanitation program: research brief. 2015. p. 8

13. WHO/Unicef Core questions on drinking-water and sanitation forhousehold surveys. 2006. http://www.who.int/water_sanitation_health/monitoring/ household_surveys/en/. Accessed 12 May 2016.

14. Bain R, Luyendijk R. Are burial or disposal with garbage safe forms of child faeces disposal? An expert consultation. Waterlines. 2015;34(3):241-54. http://dx.doi.org/10.3362/1756-3488.2015.023.

15. WHO. Global health risks: mortality and burden of disease attributable to selected major risks. Geneva: World Health Organization; 2009. p. 23.

16. Ifezulike CC, Azikiwe CCA, Modebe IA, Nwabueze SA, Amazu LU. Pattern of disposal of child faeces and other waste among community-directed distributors in Anambra East Local Government Area, Anambra State, Southeast Nigeria. URJMMS. 2015;3(2):014-20.

17. Naing $L$, Winn T, Rusli BN. Practical issues in calculating the sample size for prevalence studies. Arch Orofac Sci. 2006;1:9-14.

18. Russel K, Tilmans S, Kramer S, Sklar R, Tillias D, Davis J. User perceptions of and willingness to pay for household container-based sanitation services: experience from Cap Haitien, Haiti. Environ Urban J. 2015;27(2):525-40. doi:10.1177/0956247815596522

19. Stanton BF, Clemens JD, Aziz KMA, Rahman M. Twenty-four-hour recall, knowledge-attitude-practice questionnaires, and direct observations of sanitary practices: a comparative study. Bull World Health Organ. 1987:65(2):217-22.

20. Sudeshna R, Aparajita D. Determinants of menstrual hygiene among adolescent girls: a multivariate analysis. Natl J Community Med. 2012;3(2):294-301.

21. Aluko OO, Adebayo AE, Adebisi TF, Ewegbemi MK, Abidoye AT, Popoola BF Knowledge, attitudes, and perceptions of occupational hazards and safety practices in Nigerian healthcare workers. BMC Res Notes. 2016;9:71. doi:10.1186/s13104-016-1880-2.

22. Cronin AA, Sebayang SK, Torlesse H, Nandy R. Association of safe disposal of child feces and reported diarrhea in indonesia: need for stronger focus on a neglected risk. Int J Environ Res Public Health. 2016;13:310.

23. Curtis V, Kanki B, Mertens T, Traore E, Diallo I, et al. Potties, pits and pipes: Explaining hygiene behaviour in Burkina Faso. Soc Sci Med. 1995;41:383-93. 
24. Powell DA, Jacob CJ, Chapman BJ. Enhancing food safety culture to reduce rates of foodborne illness. Food Control. 2011;22:817e822.

25. Traoré E, Cousens S, Curtis V, Mertens T, Tall F, Traoré A, Kanki B, Diallo I, Rochereau A, Chiron JP. Child defecation behavior, stool disposal practices, and childhood diarrhoea in Burkina Faso: results from a case-control study. J Epidemiol Community Health. 1994;48(3):270-5.

26. Brown J, Cairncross S, Ensink JHJ. Water, sanitation, hygiene and enteric infections in children. Arch Dis Child. 2013;98:629-34.

27. Gil A, Lanata C, Kleinau E, Penny M. Children's feces disposal practices in developing countries and interventions to prevent diarrheoal diseases. Washington, DC: USAID; 2004.

28. Esrey SA, Potash JB, Roberts L, Schiff C. Effects of improved water supply and sanitation on ascariasis, diarrhoea, dracunculiasis, hookworm infection, schistosomiasis, and trachoma. Bull World Health Organ. 1991;69(5):609-21.

29. Sahay AK, Kumar A, Meena SAK, Krishna A, Shahnawaz K. Association of diarrhoea with practices of hand washing and excreta disposal in children. J Evol Med Dent Sci. 2015;4(34):5791-6. doi:10.14260/jemds/2015/849.

30. Freeman MC, Stocks ME, Cumming O, Jeandron A, Higgins JP, Wolf J, PrussUstun A, Bonjour S, Hunter PR, Fewtrell L, Curtis V. Hygiene and health: systematic review of handwashing practices worldwide and update of health effects. Tropical Med Int Health. 2014;19(8):906-16. http://dx.doi.org/10.1111/tmi.12339.

31. Mosley WH, Chen LC. An analytical framework for the study of child survival in developing countries. Bull World Health Organ. 1984;81(2):140-5.

32. Demberere T, Chidziya T, Ncozana T, Manyeruke N. Knowledge and practices regarding water, sanitation and hygiene (WASH) among mothers of under-fives in Mawabeni, Umzingwane District of Zimbabwe. Phys Chem Earth. 2016;92:119-24. http://dx.doi.org/10.1016/j.pce.2015.09.013.

33. Miller-Petrie MK, Voigt L, McLennan L, Cairncross S, Jenkins MW. Infant and young child feces management and enabling products for their hygienic collection, transport, and disposal in Cambodia. Am J Trop Med Hyg. 2016;94(2):456-65. doi:10.4269/ajtmh.15-0423.

34. Cohen Hubal EA, Sheldon LS, Burke JM, McCurdy TR, Berry MR, Rigas ML, Zartarian VG, Freeman NC. Children's exposure assessment: a review of factors influencing Children's exposure, and the data available to characterize and assess that exposure. Environmental Health Perspectives. 2000;108(6):475-86.

35. Moya J, Bearer CF, Etzel RA. Children's behavior and physiology and how it affects exposure to environmental contaminants. Pediatrics. 2004;113:996-1006

36. Baltazar JC, Solon FS. Disposal of faeces of children under two years old and diarrhoea incidence: a case-control study. Int J Epidemiol. 1989;18(4, Suppl 2):S16-9.

37. Azage M, Haile D. Factors associated with safe child feces disposal practices in Ethiopia: evidence from demographic and health survey. Arch Public Health. 2015;73:40. doi:10.1186/s13690-015-0090-z.

38. Majorin F, Freeman MC, Barnard S, Routray P, Boisson S, Clasen T. Child feces disposal practices in rural orissa: a cross-sectional study. PLoS ONE. 2014;9(2):e89551. doi:10.1371/journal.pone.0089551.

\section{Submit your next manuscript to BioMed Central and we will help you at every step:}

- We accept pre-submission inquiries

- Our selector tool helps you to find the most relevant journal

- We provide round the clock customer support

- Convenient online submission

- Thorough peer review

- Inclusion in PubMed and all major indexing services

- Maximum visibility for your research

Submit your manuscript at www.biomedcentral.com/submit

) Biomed Central 